\title{
PENGARUH KEPEMIMPINAN TRANSFORMASIONAL KEPALA SEKOLAH DAN PROFESIONALISME GURU TERHADAP IMPLEMENTASI MBS PADA PESANTREN DI KABUPATEN AGAM
}

\author{
Junaidi \\ LAIN Bukittinggi, alhady.junaidi@yahoo.co.id
}

Diterima: 3 Februari 2018

Direvisi : 23 April 2018

Diterbitkan: 30 Juni 2018

\begin{abstract}
Leadership of madrasah headmasters and teacher professionalism are the two things that determine the successful of implementation of school-based management. This study aims at knowing the effect of headmaster transformational leadership and professionalism of teachers either individually or collectively toward the successful of the implementation of School Based Management in pesantren in Agam District. This research is done by using quantitative approach. The population of this study is all teachers of Pesantren Agam Regency, 896 people. The samples were selected by Area sampling technique and Simple random sampling, as many as 227 teachers. Data analysis using correlation and regression techniques with the help of SPSS program. The results showed that the transformational leadership of madrasah headmasters and professionalism of teachers both individually and collectively have the affect toward the implementation of School Based Management in pesantren in Kabupaten Agam.
\end{abstract}

Keywords: Transformational Leadership, Teacher Professionalism, School Based Management

\begin{abstract}
Abstrak
Kepemimpinan kepala madrasah dan profesionalisme guru merupakan dua hal yang menentukan keberbasilan pelaksanaan manajemen berbasis sekolah. Penelitian ini bertujuan untuk mengetabui pengaruh kepemimpinan transformasional kepala madrasah dan profesionalisme guru baik secara sendiri-sendiri maupun secara bersama terbadap keberbasilan pelaksanaan Manajemen Berbasis Sekolah pada pesantren di Kabupaten Agam. Penelitian ini dilakukan dengan menggunakan pendekatan kuantitatif. Populasi penelitian ini adalah seluruh guru pesantren Kabupaten Agam berjumlah 896 orang. Sampel dipilih dengan teknik Area sampling dan Simple random sampling, sebanyak 227 orang guru. Analisis data menggunakan teknik korelasi dan regresi dengan bantuan program SPSS. Hasil Penelitian menunjuk.kan babwa kepemimpinan transformasional kepala madrasah dan profesionalisme guru baik secara sendirisendiri maupun secara bersama berpengarub terbadap pelaksanaan Manajemen Berbasis Sekolah pada pesantren di Kabupaten Agam.
\end{abstract}

Kata Kunci: Kepemimpinan Transformasional, Profesionalisme Guru, Manajemen Berbasis Sekolah

\section{PENDAHULUAN}

Pesantren sering dianggap sebagai lembaga pendidikan tradisional dan pendidikan kelas dua oleh sebahagian masyarakat Indonesia. Pemahaman terhadap pesantren sebagai lembaga tradisional, mengakibatkan pengelolaan atau manajemen pesantren menjadi lemah. Untuk itu sudah seharusnya manajemen pendidikan yang bersifat klasik ditinggalkan dan beralih ke manajemen yang aplikatif, fleksibel dan berbasis mutu, sehingga pesantren mampu menjadi lembaga pendidikan yang diperhitungkan di masyarakat. Salah satunya adalah dengan menerapkan Manajemen Berbasis Sekolah (MBS).

Manajemen Berbasis Sekolah merupakan suatu penawaran yang diberikan kepada pesantren untuk mampu menyediakan pendidikan yang lebih bermutu dan lebih memadai bagi peserta didik. Penerapan MBS akan memberi peluang bagi kepala sekolah, guru, dan peserta didik untuk melakukan 
inovasi dan improvisasi di sekolah, berkaitan dengan masalah kurikulum, pembelajaran manajerial dan lain sebagainya yang tumbuh dari aktivitas, kreativitas, dan profesionalisme yang dimiliki dalam rangka meningkatkan mutu pendidikan.

Konsep kebijakan Manajemen Berbasis Sekolah, menurut Hadiyanto ${ }^{1}$ dirumuskan sebagai model manajemen yang memberikan otonomi lebih besar kepada warga sekolah (guru, Kepala madrasah, orang tua dan masyarakat) untuk meningkatkan mutu sekolah. Kebijakan ini diharapkan dapat diterapkan disekolah-sekolah di Indonesia termasuk sekolah agama.

Adanya kewenangan dalam pengelolaan pendidikan merupakan kesempatan bagi sekolah secara optimal dan fleksibel meningkatkan kinerja staf untuk mewujudkan partisipasi langsung dengan kelompok- kelompok yang terkait, dan meningkatkan pemahaman masyarakat terhadap pendidikan. Lebih dari itu, Kepala madrasah juga berperan dalam menampung konsensus umum yang meyakini bahwa sedapat mungkin suatu keputusan sebaiknya dibuat secara demokratis dan dilaksanakan oleh mereka yang memiliki akses paling banyak terhadap informasi setempat dari mereka yang terkena hubungan dari kebijakan tersebut.

Penelitian Afriansyah, menyatakan bahwa Manajemen Berbasis Sekolah merupakan suatu konsep yang menawarkan otonomi pada sekolah untuk menentukan kebijakan sekolah dalam rangka meningkatkan mutu, efisiensi, dan pemerataan pendidikan agar dapat mengakomodasi keinginan masyarakat setempat serta menjalin kerja sama yang erat antara sekolah, masyarakat, dan pemerintah. Dengan adanya implementasi Manajemen Berbasis Sekolah diharapkan dapat meningkatkan mutu pendidikan yang ada saat

1 Hadiyanto.(2004). Mencari Sosok Desentralisasi Manajemen Pendidikan di Indonesia: Pengantar oleh H.A.R. Tilaar. Jakarta: Rineka Cipta. ini. Manajemen Berbasis Sekolah merupakan faktor penting dalam reformasi sekolah di Indonesia terhadap mendirikan sekolahsekolah yang mampu bekerja secara independen dan mendapatkan dukungan dari para stakeholder serta masyarakat setempat. ${ }^{2}$

Fakor penting dalam pelaksanaan MBS adalah kepemimpinan kepala sekolah dan profesionalisme guru. Amiruddin, Khairuddin, dan Irwan Nasution mengungkapkan bahwa faktor yang mempengaruhi pelaksanaan MBS adalah; (1) tingkat kemampuan ekonomi masyarakat, (2) social budaya dan politik, (3) taraf pendidikan masyarakat, (4) kebijakan pemerintah, (5) organisasi dan kepemimpinan Kepala madrasah, (6) strategi pembelajaran di kelas, (7) tata laksana sekolah, (8) iklim dan kultur sekolah, (9) profesionalisme guru, (10) pengawasan pendidikan dan pengajaran, dan (11)tenaga kependidikan lainnya. ${ }^{3}$ Sedangkan menurut Nurkholis, ada enam faktor yang mempengaruhi keberhasilan implementasi MBS. Keenamnya mencakup: political will, financial, sumber daya manusia, budaya sekolah, kepemimpinan, dan keorganisasian. ${ }^{4}$

Hal ini berarti bahwa keberhasilan pelaksanaan MBS tidak terlepas dari kepemimpinan Kepala madrasah yang berkualitas. Salah satu model kepemimpinan Kepala madrasah adalah kepemimpinan transformasional. Kepala madrasah yang menerapkan pola kepemimpinan transformasional akan membawa perubahan organisasi kearah yang lebih baik untuk peningkatan mutu sekolah serta memberikan kesempatan yang seluas-luasnya bagi anggota organisasi untuk turut serta berpartisipasi dalam merencanakan dan menetapkan tujuan sekolah secara bersama-sama.

2 Afriansyah, "Manajemen Berbasis Sekolab", Artikel, Fisip Administrasi Negara, Universitas Diponegoro, 2005

3 Amiruddin, dkk.. Manajemen Pendidikan Berbasis Sekolah. h. 34

4 Nurkolis. (2003). Manajemen Berbasis Sekolah. Jakarta: PT. Gramedia Widiasarana Indonesia 
Tipe kepemimpinan transformasional dapat sejalan dengan fungsi manajemen model MBS. Alasannya Pertama, adanya kesamaan yang paling utama, yaitu jalannya organisasi yang tidak digerakkan oleh birokrasi, tetapi oleh kesadaran bersama. Kedua, para pelaku mengutamakan kepentingan organisasi bukan kepentingan pribadi. Ketiga, adanya partisipasi aktif dari pengikut atau orang yang dipimpin.

Faktor lain yang juga mempengaruhi pelaksanaan Manajemen Berbasis Sekolah adalah profesionalisme guru. Profesionalisme guru merupakan kondisi, arah, nilai, tujuan dan kualitas suatu keahlian dan kewenangan dalam bidang pendidikan dan pengajaran yang berkaitan dengan pekerjaan seseorang yang menjadi mata pencaharian.

Masrukhin mengatakan bahwa profesionalisme guru merupakan salah satu faktor penentu keberhasilan pelaksanaan manajemen berbasis sekolah (MBS). Hal ini dikarenakan guru merupakan ujung tombak proses pembelajaran. Salah satu pilar dari manajemen berbasis sekolah adalah adanya inovasi pembelajaran yang muaranya adalah peningkatan hasil belajar dan mutu sekolah. ${ }^{5}$

Berdasarkan survey awal yang dilakukan pada beberapa pesantren terungkap bahwa belum terlaksananya program MBS dengan baik. ini terindikasi pada pesantren belum diberi kemandirian untuk mengelola sumber daya sendiri. Belum sepenuhnya melibatkan warga sekolah dalam pengambilan keputusan untuk melakukan perubahan. Kepala madrasah belum memandang guru sebagai mitra kerjanya, masih mengedepankan kekeluargaan dari pada profesionalitas dalam melakukan pekerjaan, sekolah masih mau diintervensi terutama oleh Yayasan.

\footnotetext{
${ }^{5}$ Masrukhin. 2009. Faktor-Faktor Penentu Keberbasilan Pelaksanaan Manajemen Berbasis Sekolab (MBS) Di Sekolah Menengah Atas (SMA) Se-Wilayah Eks Karesidenan Pati. Disertasi. Program Studi Manajemen Pendidikan, Program Pascasarjana, Universitas Negeri Semarang.
}

Masih ada guru-guru yang menolak ide-ide baru tentang pendidikan, kurangnya kreatifitas guru untuk menciptakan hal-hal baru dalam pendidikan dan pengajaran, tingkat kelulusan ujian akhir nasional santri cendrung rendah, para orang tua siswa hanya berpartisipasi dalam hal materi (dana), orang tua kurang peduli dengan kemajuan pesantren. Tidak berfungsinya komite sekolah dalam menyalurkan aspirasi orang tua dan masyarakat, Bahkan beberapa pesantren tidak memiliki komite sekolah, Yayasan lebih memegang peranan penting dalam menentukan kemajuan sekolah dibanding kepala sekolah sendiri.

Oleh karena itu, dianggap penting untuk dilakukan penelitian secara empiris tentang faktor penentu keberhasilan pelaksanaan Manajemen Berbasis Sekolah antara lain; kepemimpinan transformasional kepala madrasah dan profesionalisme guru. Penelitian ini dilakukan bertujuan untuk mengetahui pengaruh kepemimpinan transformasional kepala sekolah dan profesionalisme guru terhadap Implementasi MBS pada pesantren dikabupaten Agam.

\section{METODOLOGI PENELITIAN}

Penelitian ini adalah penelitian kuantitatif dengan pendekatan korelasional. Penelitian korelasional dalam bidang pendidikan, social dan ekonomi banyak dilakukan oleh para peneliti. Penelitian ini dilakukan ketika ingin mengetahui tentang kuat atau lemahnya hubungan variabel yang terkait dalam suatu objek atau subjek yang diteliti. Hal ini sesuai dengan anjuran Gay, bahwa:

"Correlational research is a study that involves collecting data in order to determine wether and to what degree a relationship exists between two or more quantifiable variabels". Artinya : "Penelitian Korelasi adalah sebuab studi yang melibatkan pengumpulan data untuk 

menentukan tingkatan bubungan antara dua
variabel atau lebih" 6

Analisis yang digunakan dalam penelitian ini adalah analisis deskriptif. Analisis deskriptif ialah suatu analisis untuk menjawab pertanyaan hubungan antara beberapa variabel. Variabel yang dikaji dibedakan atas dua hal, yaitu variabel bebas yang terdiri dari pengaruh kepemimpinan transformasional kepala madrasah (X1) dan Profesionalisme Guru (X2). Adapun variabel terikat adalah pelaksanaan Manajemen Berbasis Pesantren.

Populasi penelitian ini adalah seluruh guru pesantren di kabupaten Agam yang berjumlah 948 orang. Alasan peneliti mengambil guru sebagai populasi penelitian ini adalah karena guru lebih banyak terlibat dalam pelaksanaan manajemen berbasis pesantren. Alasan lainnya adalah guru dianggap akan memberikan jawaban yang obyektif tentang pelaksanaan manajemen berbasis pesantren. Data penelitian ini dikumpulkan dengan menggunakan angket. Data yang dikumpulkan dari hasil pengukuran dianalisis dengan menggunakan bantuan program computer yaitu dengan menggunakan analisis Statistical Program For Social Science (SPSS) versi 15, dan dilakukan dengan dua cara deskriptif dan analisis inferensial.

\section{HASIL PENELITIAN DAN PEMBAHASAN}

Data penelitian ini terdiri dari: pengaruh kepemimpinan transformasional kepala madrasah (X1), Profesionalisme Guru (X2) dan implementasi Manajemen Berbasis Pesantren $(\mathrm{Y})$ sebagai variabel terikat. Untuk masing-masing variabel di bawah ini akan disajikan nilai rata-rata, simpangan baku, median, modus, distribusi frekuens dari setiap variabel.

6 Gay, L.R. dan Airasian,P. (2000). Educational Research. (6 th, ed), New Jersey : Prentice-Hill. Inc.h. 275

\section{Pengaruh Kepemimpinan}

\section{Transformasional Kepala Madrasah (X1)}

Berdasarkan data penelitian untuk skor kepemimpinan Transformasional kepala madrasah diperoleh rentang empiris 143 dengan skor terendah 59 dan skor tertinggi 202. Dari analisis data pada halaman 252, diketahui skor rata-rata sebesar 139,42, simpangan baku 33,17, median 140., modus 114, banyaknya kelas 16 dan panjang kelas 9 serta distribusi frekuensi sebagaimana tampak pada Tabel berikut:

Berdasarkan hasil yang tertera pada Tabel di atas, dapat dijelaskan bahwa 2,2 \% (pada nomor 8) dari jumlah responden yang memperoleh skor rata-rata dari skor pengaruh kepemimpinan transformasional kepala madrasah, 106 responden (46,7\%) memiliki skor dibawah rata-rata, dan 116 responden $(51,1 \%)$ memiliki skor di atas rata-rata.

\section{Profesionalisme guru $\left(\mathrm{X}^{2}\right)$}

Berdasarkan data penelitian untuk skor profesionalisme guru diperoleh rentang empiris 131 dengan skor terendah 52 dan skor tertinggi 183. Dari analisis data pada halaman 255, diketahui skor rata-rata sebesar 126,82, simpangan baku 29,86, median 133, modus 148, banyaknya kelas 12 dan panjang kelas 11 serta distribusi frekuensi.

Berdasarkan hasil olah data statistik yang dilakukan, 6,6\% dari jumlah responden yang memperoleh skor rata-rata dari profesionalisme guru, 92 responden (40,4\%) memiliki skor di bawah rata-rata, dan 120 responden $(52,9 \%)$ memiliki skor di atas ratarata.

\section{Pelaksanaan MBS/S (Y)}

Berdasarkan data penelitian untuk skor pelaksanaan Manajemen Berbasis Pesantren diperoleh rentang empiris 144 dengan skor terendah 55 dan skor tertinggi 199. Dari analisis data pada halaman 261, diketahui skor rata-rata sebesar 147,13, simpangan baku 32,34, 
median 159, modus 174, banyaknya kelas 16 dan panjang kelas 9 serta distribusi frekuensi.

Berdasarkan hasil olah data statistik, dapat dijelaskan bahwa 3,9\% dari jumlah responden memiliki skor rata-rata dari skor pelaksanaan Manajemen Berbasis Pesantren, 88 responden (38.8\%) memiliki skor di bawah rata-rata, dan 130 responden $(57,3 \%$ memiliki skor di atas rata-rata.

\section{Pengujian Hipotesis Pertama}

Hipotesis yang diajukan dalam penelitian ini adalah "Terdapat pengaruh yang signifikan kepemimpinan transformasional kepala madrasah $\left(\mathrm{X}_{1}\right)$ terhadap pelaksanaan Manajemen Berbasis Sekolah pada pesantrenpesantren di Kabupaten Agam.

Dari hasil pengujian data dengan análisis regresi linear sederhana terhadap Pengaruh kepemimpinan transformasional kepala madrasah $\left(\mathrm{X}_{1}\right)$ terhadap pelaksanaan Manajemen Berbasis Pesantren pada pesantren-pesantren di Kabupaten Agam (Y) menghasilkan koefisien arah regresi b sebesar 0,563 dan konstanta a sebesar 68,603. Dengan demikian bentuk hubungan antara kedua variabel tersebut dapat dinyatakan oleh persamaan regresi $\hat{Y}=68,603+0,563 \mathrm{X}_{1}$. Sebelum digunakan untuk keperluan prediksi, persamaan regresi ini harus memenuhi syarat kelinearan dan keberartian.

Untuk mengetahui derajat kelinearan dan keberartian persamaan regresi tersebut, maka dilakukan uji F. Adapun hasilnya dapat dilihat pada tabel.

Dari hasil analisis varians di atas dapat disimpulkan bahwa bentuk hubungan antara Pengaruh kepemimpinan transformasional kepala madrasah $\left(\mathrm{X}_{1}\right)$ terhadap pelaksanaan Manajemen Berbasis Pesantren (Y) adalah berarti dan linear, dengan demikian model persamaan regresi ini dapat digunakan untuk memprediksi. Model persamaan regresi ini mengandung arti bahwa apabila kepemimpinan transformasional kepala madrasah ditingkatkan satu skor maka kecendrungan pelaksanaan Manajemen Berbasis Pesantren meningkat sebesar 0,563 skor pada konstanta 68,603.

Analisis korelasi terhadap pasangan data dari kedua variabel tersebut menghasilkan koefisien korelasi product moment sebesar $\mathrm{r}_{\mathrm{y} 1}=$ 0,578. Untuk uji keberartian koefisien korelasi disajikan pada tabel berikut ini.

Berdasarkan uji keberartian korelasi antara pasangan skor pengaruh kepemimpinan transformasional kepala madrasah $\left(\mathrm{X}_{1}\right)$ terhadap pelaksanaan Manajemen Berbasis Pesantren (Y) sebagaimana terlihat pada tabel diatas diperoleh signifikansi $t_{\text {hitung }}=$ $10.623>\mathrm{t}_{\text {tabel }}=2.576$ pada taraf siginifikansi $\alpha=$ 0.01 , jadi dapat disimpulkan bahwa koefisien korelasi $r_{y 1}=0,578$ sangat signifikan. Dengan demikian $\mathrm{H}_{0}$ yang mengatakan tidak terdapat pengaruh kepemimpinan transformasional kepala madrasah $\left(\mathrm{X}_{1}\right)$ terhadap pelaksanaan Manajemen Berbasis Pesantren (Y) ditolak, konsekuensinya H1 diterima. Temuan ini menyimpulkan bahwa terdapat pengaruh yang signifikan antara kepemimpinan transformasional kepala madrasah $\left(\mathrm{X}_{1}\right)$ terhadap pelaksanaan Manajemen Berbasis Sekolah (Y). Hal ini berarti semakin tinggi pengaruh kepemimpinan transformasional kepala madrasah maka semakin tinggi pula keberhasilan pelaksanaan Manajemen Berbasis Sekolah.

Hasil análisis juga menunjukkan koefisien determinasinya sebesar 0,334. Ini berarti 33,4\% varians pelaksanaan Manajemen Berbasis Sekolah dijelaskan oleh variabel pengaruh kepemimpinan transformasional kepala madrasah.

\section{Pengujian Hipotesis Kedua}

Hipotesis kedua yang diajukan dalam penelitian ini adalah Terdapat pengaruh yang signifikan Profesionalisme Guru $\left(\mathrm{X}_{2}\right)$ terhadap Pelaksanaan Manajemen Berbasis Pesantren pada pesantren-pesantren di Kabupaten Agam. 
Dari hasil analisis regresi linear sederhana terhadap pasangan data penelitian antara variabel Profesionalisme Guru $\left(\mathrm{X}_{2}\right)$ terhadap Pelaksanaan Manajemen Berbasis Pesantren pada pesantren-pesantren di Kabupaten Agam (Y) menghasilkan koefisien arah regresi b sebesar 0,415 dan konstanta a sebesar 94,457. Dengan demikian bentuk hubungan antara kedua variabel tersebut dapat dinyatakan oleh persamaan regresi $\hat{Y}=94,457+0,415 \mathrm{X}_{2}$. Sebelum digunakan untuk keperluan prediksi, persamaan regresi ini harus memenuhi syarat kelinearan dan keberartian. Asumsi lain dari penelitian korelasional adalah linearitas model regresi. Peramalan atas variabel terikat dan variabel bebas dapat dilakukan bila variabel bebas dan variabel terikat berhubungan dalam model regresi yang bersifat linear. Disamping model regresi bersifat linear, harus pula diuji bahwa model regresi cukup berarti atau signifikan. Bila model regresi cukup signifikan maka model regresi cukup kuat digunakan untuk meramalkan variabel terikat dari variabel bebas.

Untuk mengetahui derajat kelinearan dan keberartian persamaan regresi tersebut, maka perlu dilakukan uji F. Adapun hasilnya dapat diungkapkan pada tabel.

Pelaksanaan Manajemen Berbasis Pesantren meningkat sebesar 0,415 skor pada konstanta 94,457. Hasil analisis varians di atas dapat disimpulkan bahwa bentuk hubungan antara Profesionalisme guru $\left(\mathrm{X}_{2}\right)$ terhadap pelaksanaan Manajemen Berbasis Pesantren (Y) adalah berarti dan linear, dengan demikian model persamaan regresi ini dapat digunakan untuk memprediksi. Model persamaan regresi ini mengandung arti bahwa apabila profesionalisme guru ditingkatkan satu skor maka kecendrungan pelaksanaan Manajemen Berbasis Pesantren meningkat sebesar 0,415 skor pada konstanta 94,457.

Analisis korelasi terhadap pasangan data dari kedua variabel tersebut menghasilkan koefisien korelasi product moment sebesar $\mathrm{r}_{\mathrm{y} 2}=$
0,384. Untuk uji keberartian koefisien korelasi disajikan pada tabel berikut ini.

Dari hasil uji keberartian korelasi antara pasangan skor Profesionalisme guru $\left(\mathrm{X}_{2}\right)$ terhadap pelaksanaan Manajemen Berbasis Pesantren (Y) sebagaimana terlihat pada tabel diperoleh $\mathrm{t}_{\text {hitung }}=6.237>\mathrm{t}_{\text {tabel }}=$ 2.576 pada taraf signifikansi $\alpha=0,01$. Jadi dapat disimpulkan bahwa koefisien korelasi ry2 $=0,384$ sangat signifikan. Dengan demikian Ho yang mengatakan tidak terdapat kontribusi Profesionalisme guru $\left(\mathrm{X}_{2}\right)$ terhadap pelaksanaan Manajemen Berbasis Pesantren (Y) ditolak, konsekuensinya H1 diterima. Temuan ini menyimpulkan bahwa terdapat kontribusi yang berarti antara Profesionalisme guru $\left(\mathrm{X}_{2}\right)$ terhadap pelaksanaan Manajemen Berbasis Pesantren (Y). Hal ini berarti semakin tinggi profesionalisme guru maka, semakin tinggi pula keberhasilan pelaksanaan Manajemen Berbasis Pesantren.

Hasil analisis juga menunjukkan koefisien determinasinya sebesar 0,147. Ini berarti $14,7 \%$ varians pelaksanaan Manajemen Berbasis Pesantren dijelaskan oleh variabel profesionalisme guru.

\section{Pengujian Hipotesis Ketiga}

Hipotesis ketiga yang diajukan dalam penelitian ini adalah Terdapat pengaruh yang signifikan Kepemimpinan transformasioal kepala sekolah (X1) dan Profesionalisme Guru $\left(\mathrm{X}_{2}\right)$ terhadap Pelaksanaan Manajemen Berbasis Pesantren pada pesantren-pesantren di Kabupaten Agam. Hipotesis ketiga ini dilakukan dengan uji F. Uji F digunakan untuk mengetahui tingkat signifikansi pengaruh variabel-variabel independen secara bersamasama (simultan) terhadap variabel dependen. Uji $F$ dilakukan dengan dengan cara membandingkan antara nilai Fhitung dengan Ftabel.

Dari hasil hitung statistik, didapatkan hasil bahwa nilai $\mathrm{F}_{\text {hitung }}=44,829>\mathrm{F}_{\text {tabel }} 6,76$ pada taraf signifikan $\alpha=0,01$. Hal ini menunjukkan bahwa model regresi jamak 
signifikan atau berarti. Karena tingkat signifikan lebih kecil dari 0,05 maka model regresi ini dapat dipakai untuk pelaksanaan Manajemen Bebasis Sekolah. Dengan kata lain dapat dikatakan bahwa variabel Kepemimpinan transformasional kepala madrasah dan profesionalisme guru secara bersama-sama (simultan) berpengaruh secara signifikan terhadap variabel pelaksanaan Manajemen Bebasis Sekolah.

\section{PEMBAHASAN}

Berdasarkan perolehan data dan hasil pengujian hipotesis secara statistik menunjukkan bahwa terdapat pengaruh yang signifikan antara variabel terikat (Y) Pelaksanaan Manajemen Berbasis Sekolah dengan Pengaruh kepemimpinan transformasional kepala madrasah $\left(\mathrm{X}_{1}\right)$.

\section{Pengaruh Kepemimpinan}

Transformasional Kepala Madrasah terhadap Pelaksanaan Manajemen Berbasis Sekolah.

\begin{tabular}{lcr}
\multicolumn{2}{c}{ Berdasarkan temuan } & penelitian \\
dijelaskan & bahwa & kepemimpinan \\
transformasional & kepala & madrasah \\
berpengaruh & terhadap & Pelaksanaan \\
Manajemen Berbasis Sekolah pada pesantren- \\
pesantren di kabupaten & Agam. Hal ini \\
menunjukkan & bahwa & kepemimpinan \\
transformasional kepala & madrasah dapat \\
dijadikan salah satu faktor yang berarti dalam \\
Pelaksanaan Manajemen Berbasis Sekolah.
\end{tabular}
Kepemimpinan merupakan salah satu faktor yang menentukan kesuksesan implementasi MBS. Dalam Manajemen berbasis sekolah dimana memberikan keleluasaan kepada sekolah untuk mengelola potensi yang dimiliki dengan melibatkan semua unsur stakeholder untuk mencapai peningkatan kualitas sekolah tersebut. Karena sekolah memiliki kewenangan yang sangat luas itu maka kehadiran figur pemimpin menjadi sangat penting. Kepemimpinan yang baik tentunya sangat berhubungan pada tercapai tidaknya tujuan organisasi karena pemimpin memiliki pengaruh terhadap kinerja yang dipimpinnya.

Peningkatkan kualitas pendidikan dalam suatu organisasi sekolah di pengaruhi oleh kualitas pimpinan dalam hal ini adalah Kepala madrasah. Salah satu kekuatan efektivitas dalam pengelolaan sekolah yang berperan bertanggung jawab menghadapi perubahan adalah kepemimpinan Kepala madrasah. Yaitu perilaku Kepala madrasah yang mampu memprakarsai pemikiran baru dalam proses interaksi diingkungan sekolah dengan melakukan tujuan, prosedur, input, proses dan output dari suatu sekolah sesuai dengan tuntutan perkembangan. ${ }^{7}$

Penelitian yang serupa juga menghasilkan suatu kesimpulan yang sama bahwa kepemimpinan transformasional kepala madrasah mempengaruhi pelaksanaan Manajemen Berbasis Pesantren. Penelitian tentang kepemimpinan pendidikan sebagaimana yang dilakukan oleh Borko, Wolf, Simone \& Uchiyama menunjukkan bahwa kepemimpinan memegang peranan penting, atau menjadi faktor utama, yang mendorong kesuksesan upaya-upaya reformasi sekolah. ${ }^{8}$

Kepemimpinan Kepala madrasah akan sangat berpengaruh bahkan sangat menentukan terhadap kemajuan sekolah. Oleh karena itu dalam pendidikan modern kepemimpinan Kepala madrasah merupakan jabatan strategis dalam mencapai tujuan pendidikan. Kepemimpinan yang sesuai dengan model Manajemen Berbasis Pesantren adalah kepemimpinan transformasional.

Kepemimpinan transformasional dapat dicirikan dengan adanya proses untuk membangun komitmen bersama terhadap sasaran organisasi dan memberikan kepercayaan kepada para pengikut untuk mencapai sasaran. Dalam kepemimpinan transformasional menurut Burns,

7 Daryanto.2001. Administrasi Pendidikan. Jakarta: Rineka Cipta.h. 81

${ }^{8}$ Borko, H., Wolf,S., Simone, G., \& Uchiyama, K. (2003). "Schools in Transition: 
"pemimpin mencoba menimbulkan kesadaran dari para pengikut dengan menyerukan citacita yang lebih tinggi dan nilai-nilai moral". Masih menurut Burns, kepemimpinan transformasional berbeda dengan kepemimpinan transaksional yang didasarkan atas kekuasaan birokratis dan memotivasi para pengikutnya demi kepentingan diri sendiri. ${ }^{9}$

Kepemimpinan transformational mampu mentransformasi dan memotivasi para pengikutnya dengan cara; (1) membuat mereka sadar mengenai pentingnya suatu pekerjaan, (2) mendorong mereka untuk lebih mementingkan organisasi daripada kepentingan diri sendiri, dan (3) mengaktifkan kebutuhan-kebutuhan pengikut pada tarap yang lebih tinggi. Tipe kepemimpinan transformasional dapat sejalan dengan fungsi manajemen model MBS.

Keberhasilan MBS ditentukan oleh kepemimpinan dan manajemen Sekolah yang baik. MBS akan berhasil jika ditopang oleh kemampuan profesional Kepala madrasah dalam memimpin dan mengelola Sekolah secara tepat dan akurat, serta mampu menciptakan iklim organisasi di Sekolah yang mendukung terjadinya proses belajar mengajar.

Kondisi kepemimpinan kepala madrasah yang terjadi pada pesantrenpesantren di kabupaten Agam, dapat dikelompokkan kepada tiga bentuk sesuai dengan bentuk pesantren yang ada di kabupaten Agam yakni; 1) Madrasah Tarbiyah Islamiyah (MTI), 2) Pondok pesantren Modern Diniyah, dan 3) Pondok pesantren Mu'alimin Muhammadiyah.

Ketiga bentuk pesantren di atas, melahirkan tiga bentuk kepemimpinan kepala madrasah di kabupaten Agam. Pertama, kepala madrasah diberi kewenangan penuh dalam mengelola pesantren. Pada bentuk yang

9 Burns, J.M (1978) Leadership Harper \& Row, New York dalam Rumtini (1977) Transformational and Transactional Leadership Performance of Principals of Junior Secondary School in Indonesia, unpublished thesis. pertama ini, pesantren tersebut tetap memiliki yayasan, tetapi yayasan yang ada tidak bersifat kekeluargaan, tetapi terdiri dari orang-orang yang berpengaruh di daerah tersebut yang diberi kepercayaan oleh masyarakat untuk menjadi pengurus yayasan pesantren. Pada pesantren model ini, kepala madrasah diberikan kewenangan penuh untuk mengelola madrasah atau pesantren. Permasalahan yang muncul pada model pertama ini adalah pengangkatan kepala madrasah tidak berdasarkan jenjang karir seperti halnya disekolah umum. Bahkan tidak jarang yang menjadi kepala sekolah adalah orang yang diangkat dari luar pesantren. Di samping itu, permasalahan lain yang muncul adalah adanya perebutan pucuk pimpinan. Hal ini berakibat pada disharmonisasi dilingkungan pesantren.

Kedua, kepala madrasah kurang diberi hak otonom untuk mengelola madrasah atau pesantren. Hal ini dikarenakan pesantren atau madrasah yang ada adalah milik keluarga, sehingga intervensi yayasan terhadap kepala madrasah begitu kuat. Bahkan ada yayasan yang berperan ganda, disamping sebagai ketua yayasan juga sebagai kepala madrasah. Pada bentuk yang kedua ini, kepemimpinan kepala madrasah lebih cendrung bergaya otoriter. Kepemimpinan otoriter tentu saja bertentangan dengan konsep Manajemen Berbasis Pesantren yang menganjurkan gaya kepemimpinan transformasional. Beberapa pesantren di Kabupaten Agam menganut model yang kedua ini. Akibatnya yayasan memainkan peran yang sangat dominan dalam mengelola dan mengambil keputusan terhadap persoalan pesantren.

Bentuk yang ketiga, kepemimpinan kepala madrasah semi otonom Di katakan semi otonom, karena kepala madrasah diberi kewenangan dalam mengelola madrasah tapi tetap harus berpegang pada aturan yang dibuat oleh pimpinan pusat. Kondisi ini di alami oleh pesantren Mu'alimin Muhammadiyah. 
Melihat kenyataan di atas, secara umum dapat dikatakan bahwa yayasan memainkan peranan yang lebih besar dalam mengelola madrasah atau pesantren dibanding kepala madrasah. Hal ini menyebabkan manajemen pesantren menjadi tidak efektif. World Bank mencatat adanya tiga faktor manajemen sekolah yang tidak efektif di Indonesia, ${ }^{10}$ yaitu; (1) kepala sekolah umumnya memiliki otonomi sangat terbatas dalam mengelola sekolah dan memutuskan pengalokasian sumber daya; (2) kepala sekolah diidentifikasi kurang memiliki keterampilan mengelola sekolah dengan baik; (3) kecilnya peran serta masyarakat dalam pengelolaan sekolah, padahal dukungan masyarakat merupakan bagian dari peran kepemimpinan kepala sekolah. Keterampilan ini penting manakala fungsi-fungsi pendidikan didesentralisasikan.

Berkenaan dengan otonomi kepala madrasah, menurut Sagala, terbelenggunya kreativitas kepala madrasah karena kaku dan sentralistiknya birokrasi pendidikan, menghambat terjadinya inovasi baru dari sekolah. ${ }^{11}$ Hal ini semata-mata bukan karena kualitas SDM-nya yang rendah, tetapi karena sistem tidak mendukung atau memberi ruang gerak untuk suatu kreativitas dan inovasi. Kondisi inilah yang melanda beberapa pesantren di kabupaten Agam.

Di samping persoalan kepemimpinan dan yayasan yang dialami oleh pesantren, komite sekolah juga terlihat kurang mampu menjalankan fungsi sebagaimana mestinya. Komite sekolah hanya berperan dalam memobilisasi sumbangan. Seharusnya komite sekolah berperan dalam membantu dan mengawasi pelaksanaan pendidikan.

10 The word Bank. (1998). Education in Indonesia : From Crisis to Recovery. World Bank: Education Sector Unit East Asia and Pasific regional Office.

11 Sagala. Syaiful, (2005). Manajemen Berbasis Sekolah dan Masyarakat. Strategi memenangkan persaingan mutu. Malang: Nimas Multima.h. 147

\section{Pengaruh Profesionalisme Guru terhadap Pelaksanaan Manajemen Berbasis Sekolah}

Temuan penelitian menjelaskan bahwa antara profesionalisme guru dengan pelaksanaan Manajemen Berbasis Sekolah mempunyai hubungan yang signifikan. Hal ini menunjukkan bahwa profesionalisme guru dapat dijadikan salah satu faktor yang berarti dalam pelaksanaan Manajemen Berbasis Sekolah.

Hasil penelitian ini relevan dengan hasil penelitian yang dilakukan oleh Masrukhin tentang Faktor-Faktor Penentu Keberhasilan Pelaksanaan Manajemen Berbasis Sekolah (MBS) Di Sekolah Menengah Atas (SMA) SeWilayah Eks Karesidenan Pati. Salah satu faktor penentu keberhasilan Manajemen Berbasis Sekolah tersebut adalah profesionalisme guru. Hal ini dikarenakan guru merupakan ujung tombak proses pembelajaran. ${ }^{12}$ Salah satu pilar dari manajemen berbasis sekolah adalah adanya inovasi pembelajaran yang muaranya adalah peningkatan hasil belajar dan mutu sekolah.

Ini membuktikan bahwa guru yang profesional akan selalu melakukan inovasiinovasi atau pembaharuan-pembaharuan untuk peningkatan mutu pendidikan (sekolah) dan tentu saja pengaruhnya kepada prestasi siswa. Hal ini diperkuat oleh pendapat Paul Suparno yang mengatakan bahwa Pedagogi reflektif menunjuk tanggungjawab pokok pembentukan moral maupun intelektual dalam sekolah terletak pada para guru. ${ }^{13}$ Karena dengan dan melalui peran para guru hubungan personal autentik untuk penanaman nilai-nilai bagi para siswa berlangsung. Untuk itu guru yang profesional dalam kerangka pengembangan MBS perlu memiliki kompetensi antara lain kompetensi kepribadian (integritas, moral,

12 Masrukhin. 2009. Faktor-Faktor Penentu Keberbasilan Pelaksanaan Manajemen Berbasis Sekolab (MBS) Di Sekolah Menengah Atas (SMA) Se-Wilayah Eks Karesidenan Pati. Disertasi...

13 Suparno Paul, dkk, 2002, Reformasi Pendidikan Sebuah Rekomendasi, Yokyakarta: Kanisius. 
etika dan etos kerja), kompetensi akademik (sertifikasi kependidikan, menguasai bidang tugasnya) dan kompetensi kinerja (terampil dalam pengelolaan pembelajaran).

Oleh karena itu, upaya untuk meningkatkan profesionalitas guru perlu dilakukan oleh masing-masing pesantren dan madrasah dikabupaten Agam, sebab hal itu akan menentukan keberhasilan pelaksanaan Manajemen Berbasis Sekolah. Jika pelaksanaan Manajemen Berbasis Sekolah berhasil dilakukan dengan fondasi profesionalitas guru maka akan berpengaruh pada mutu pendidikan sesuai dengan tujuan dilaksanakannya MBS di sekolah-sekolah.

Dari penjelasan di atas dapat diambil kesimpulan bahwa apabila faktor kepemimpinan kepala sekolah dan profesionalisme guru secara bersama-sama diimplementasikan di sekolah, maka program Manajemen Berbasis Sekolah akan berhasil dilaksanakan dengan baik. Semakin bagus kepemimpinan kepala madrasah, dan profesionalisme guru, maka akan semakin baik pula penerapan Manajemen Berbasis Sekolah pada pesantren dan madrasah di kabupaten Agam.

\section{PENGARUH KEPEMIMPINAN TRANSFORMASIONAL KEPALA MADRASAH DAN \\ PROFESIONALISME GURU TERHADAP PELAKSANAAN MANAJEMEN BERBASIS SEKOLAH}

Berdasarkan temuan penelitian, terdapat pengaruh kepemimpinan transformasional kepala madrasah dan profesionalisme guru secara bersama-sama dengan pelaksanaan Manajemen Berbasis Pesantren. Hal ini menunjukkan bahwa kepemimpinan transformasional kepala madrasah dan profesionalisme guru secara bersama-sama dapat dijadikan sebagai faktor penentu keberhasilan pelaksanaan Manajemen Berbasis Pesantren. Temuan ini tidak bertentangan dengan kajian teori yang membahas tentang keterkaitan antara kepemimpinan transformasional kepala madrasah dan profesionalisme guru dengan pelaksanaan Manajemen Berbasis Pesantren.

Secara sederhana kepemimpinan transformasional dapat diartikan sebagai proses untuk merubah dan mentransformasikan individu agar mau berubah dan meningkatkan dirinya, yang didalamnya melibatkan motif dan pemenuhan kebutuhan serta penghargaan terhadap para bawahan. Kepemimpinan transformasional dapat dicirikan dengan adanya proses untuk membangun komitmen bersama terhadap sasaran organisasi dan memberikan kepercayaan kepada para pengikut untuk mencapai sasaran. Dalam kepemimpinan transformasional menurut Burns mengungkapkan bahwa, pemimpin mencoba menimbulkan kesadaran dari para pengikut dengan menyerukan cita-cita yang lebih tinggi dan nilai-nilai moral.

Kepemimpinan transformational mampu mentransformasi dan memotivasi para pengikutnya dengan cara; (1) membuat mereka sadar mengenai pentingnya suatu pekerjaan,(2) mendorong mereka untuk lebih mementingkan organisasi daripada kepentingan diri sendiri, dan (3) mengaktifkan kebutuhan-kebutuhan pengikut pada tarap yang lebih tinggi. Tipe kepemimpinan transformasional dapat sejalan dengan fungsi manajemen model MBS.

Pertama, adanya kesamaan yang paling utama, yaitu jalannya organisasi yang tidak digerakkan oleh birokrasi, tetapi oleh kesadaran bersama. Kedua, para pelaku mengutamakan kepentingan organisasi bukan kepentingan pribadi. Ketiga, adanya partisipasi aktif dari pengikut atau orang yang dipimpin.

Menurut Mulyasa, Kepala madrasah merupakan "sosok kunci" (the key person) keberhasilan peningkatan kualitas pendidikan 
di sekolah dalam kerangka implementasi MBS. ${ }^{14}$ Oleh karena itu, dalam implementasi MBS kepala sekolah harus memiliki visi, misi, dan wawasan yang luas tentang sekolah yang efektif serta kemampuan profesional dalam mewujudkannya melalui perencanaan, kepemimpinan, manajerial, dan supervisi pendidikan. Kepala sekolah juga dituntut untuk menjalin kerjasama yang harmonis dengan berbagai pihak yang terkait dengan program pendidikan di sekolah. Singkatnya, dalam implementasi MBS, kepala sekolah harus mempu berperan sebagai educator, manajer, administrator, supervisor, leader, innovator dan motivator.

Dari pendapat di atas jelas bahwa, kepemimpinan kepala madrasah menjadi kunci keberhasilan pelaksanaan Manajemen Berbasis Pesantren. Kepala madrasah yang menerapkan kepemimpian transformasional akan mampu membawa perubahan kearah perbaikan dan peningkatan mutu serta mampu memberdayakan guru-guru. Dengan diberdayakannya para guru maka akan semakin meningkat profesionalitas mereka dalam menjalankan tugasnya dan hal itu juga akan berpengaruh kepada terwujudnya budaya organisasi yang berorientasi kepada mutu.

Menurut Nurkholis sumber daya manusia merupakan faktor yang sangat penting dalam mendukung keberhasilan implementasi MBS. Ketersedian sumber daya manusia yang mendukung implementasi MBS belum cukup. Karena MBS merupakan hal yang baru dan hanya sebagian orang yang mempunyai keahlian dan keterampilan dalam mendukung implementasi MBS. ${ }^{15}$ Oleh karena itu, dukungan untuk on the job training, atau in service training dalam kerangka peningkatan pengetahuan dan kemampuan tentang MBS perlu dilakukan.

14 Mulyasa.(2004). Manajemen Berbasis Sekolab: Konsep, Strategi, dan Implikasi..Bandung: Remaja Rosdakarya h. 98

15 Nurkolis. (2003). Manajemen Berbasis Sekolah.
Peningkatan mutu yang berbasis sekolah (MPMBS) mensyaratkan adanya guruguru yang memilki pengetahuan yang luas, kematangan, dan mampu menggerakkan dirinya sendiri dalam rangka meningkatkan mutu pendidikan. Oleh karena itu perlunya dilakukan peningkatan mutu profesi seorang guru baik secara formal maupun secara informal. Peningkatan secara formal merupakan peningkatan mutu melalui pendidikan dalam berbagai kursus, sekolah, maupun kuliah di perguruan tinggi atau lembaga lain yang berhubungan dengan bidang profesinya. Di samping itu, secara formal guru dapat saja meningkatkan mutu profesinya dengan mendapatkan informasi dari media massa (surat kabar, majalah, radio, televisi dan lain-lain) atau dari buku-buku yang sesuai dengan bidang profesi yang bersangkutan.

Dari penjelasan di atas dapat diambil kesimpulan bahwa apabila faktor kepemimpinan kepala sekolah dan profesionalisme guru secara bersama-sama diimplementasikan di sekolah, maka program Manajemen Berbasis Sekolah akan berhasil dilaksanakan dengan baik. Semakin bagus kepemimpinan kepala madrasah, dan profesionalisme guru, maka akan semakin baik pula penerapan Manajemen Berbasis Sekolah pada pesantren dan madrasah di kabupaten Agam.

\section{KESIMPULAN DAN SARAN}

\section{Kesimpulan}

Berdasarkan analisis data dan pembahasan di atas maka dapat disimpulkan hasil penelitian sebagai berikut:

Kepemimpinan transformasional kepala madrasah berpengaruh terhadap pelaksanaan Manajemen Berbasis Sekolah. Hal ini berarti bahwa apabila kepemimpinan transformasional kepala sekolah diperbaiki melalui membangun perubahan dengan sikap keteladanan, motivasi inspirasional, pertimbangan individual dan stimuli h. 264 
intelektual. Maka pelaksanaan Manajemen Berbasis Sekolah akan berhasil dengan baik.

Profesionalisme guru berpengaruh terhadap pelaksanaan Manajemen Berbasis Sekolah . Hal ini berarti bahwa apabila profesionalisme guru ditingkatkan maka pelaksanaan Manajemen Berbasis Sekolah akan berjalan dengan baik.

Kepemimpinan transformasional kepala madrasah dan profesionalisme guru secara bersama-sama berpengaruh terhadap pelaksanaan Manajemen Berbasis Sekolah. Artinya bahwa apabila secara bersama-sama kepemimpinan transformasional kepala madrasah dan profesionalisme guru diperbaiki maka pelaksanaan Manajemen Berbasis Sekolah akan berjalan dengan baik.

\section{Saran}

Berdasarkan hasil kesimpulan dan implikasi di atas, dapat dikemukakan beberapa saran serta rekomendasi kepada berbagai pihak, sebagai berikut:

Kepada Kepala Kantor Kementerian Agama Kabupaten Agam, untuk lebih memberikan bekal kepada kepala pesantren/madrasah terutama berkaitan dengan kepemimpinan transformasional dalam rangka pelaksanaan Manajemen Berbasis Sekolah. Disamping itu perlu juga meningkatkan profesionalisme guru-guru pesantren untuk meningkatkan mutu pesantren atau madrasah, baik melalui lokakarya, seminar maupun pelatihan sehingga program Manajemen Berbasis Sekolah bisa berjalan dengan baik.

Kepala sekolah diharapkan lebih meningkatkan profesionalitas kepemimpinannya dengan cara, bekerjasama dan aktif dalam musyawarah kerja kepala sekolah (MKKS), mengikuti pelatihan manajemen kepala sekolah, melakukan rapat secara rutin dengan melibatkan semua warga sekolah, mendengarkan pendapat/masukan dari guru dan warga sekolah lainnya, mengikuti seminar dan workshop tentang kepemimpinan kepala sekolah secara berkala, mengikuti kursus singkat (short course) dan studi banding tentang kepemimpinan kepala sekolah dan studi lanjut kejenjang yang lebih tinggi.

Pendidik diharapkan berusaha meningkatkan profesionalitasnya, dengan cara, aktif dalam kegiatan musyawarah guru mata pelajaran (MGMP), aktif mengikuti seminar dan lokakarya pendidikan, aktif mengikuti diskusi-diskusi profesional, studi lanjut ke jenjang yang lebih tinggi. 


\section{DAFTAR KEPUSTAKAAN}

Afriansyah, "Manajemen Berbasis Sekolab", Artikel, Fisip Administrasi Negara, Universitas Diponegoro, 2005

Amiruddin, S.,Khairuddin, dan Irwan,N. (2006). Manajemen Pendidikan Berbasis Sekolah. Ciputat: Quantum Teaching.

Borko, H., Wolf,S., Simone, G., \& Uchiyama, K. (2003). "Schools in Transition:

Daryanto.2001. Administrasi Pendidikan. Jakarta: Rineka Cipta.h. 81

Gay, L.R. dan Airasian,P. (2000). Educational Research. (6 th, ed), New Jersey : Prentice-Hill. Inc.

Hadiyanto.(2004). Mencari Sosok Desentralisasi Manajemen Pendidikan di Indonesia: Pengantar oleh H.A.R. Tilaar. Jakarta: Rineka Cipta.

IMasrukhin. 2009. Faktor-Faktor Penentu Keberhasilan Pelaksanaan Manajemen Berbasis Sekolah (MBS) Di Sekolah Menengah Atas (SMA) Se-Wilayah Eks Karesidenan Pati. Disertasi. Program Studi Manajemen Pendidikan, Program Pascasarjana, Universitas Negeri Semarang.

Mulyasa.(2004). Manajemen Berbasis Sekolah : Konsep, Strategi, dan Implikasi. Bandung: Remaja RosdaKarya.

Mulyasa. E. (2003). Manajemen Berbasis Sekolah , Jakarta:Rosda

Nurkolis. (2003). Manajemen Berbasis Sekolah . Jakarta: PT. Gramedia Widiasarana Indonesia

Sagala. Syaiful, (2005). Manajemen Berbasis Sekolah dan Masyarakat. Strategi memenangkan persaingan mutu. Malang: Nimas Multima.

Suparno Paul, dkk, 2002, Reformasi Pendidikan Sebuah Rekomendasi, Yokyakarta: Kanisius.

The word Bank. (1998). Education in Indonesia : From Crisis to Recovery. World Bank: Education Sector Unit East Asia and Pasific regional Office. 
Halaman ini tidak disengaja kosong 